\title{
Years of life lost due to colorectal cancer in Poland between 2000 and 2014 according to voivodships
}

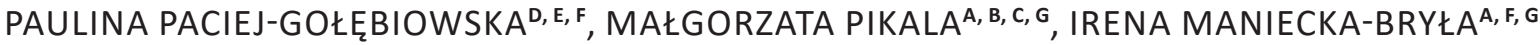 \\ Department of Epidemiology and Biostatistics, Medical University of Lodz, Poland
}

A - Study Design, B - Data Collection, C - Statistical Analysis, D - Data Interpretation, E - Manuscript Preparation, F - Literature

Search, G - Funds Collection

Summary Background. Colorectal cancers (CRCS) are among the most important oncological causes of death in Europe. Poland belongs to countries where the mortality rates due to this cause exceed the average values for EU-28.

Objectives. Comparison of the number of years of life lost (YLLs) due to CRC between 2000 and 2014 in Poland by voivodships.

Material and methods. The study was based on a dataset containing information from the death certificates of Poles who died in 2000 and 2014 (368,028 and 376,467 records, respectively). The data on deaths caused by CRC (C18-C21 according to ICD-10) was used for the analysis (8,517 deaths in 2000 and 11,411 deaths in 2014). SEYLL (Standard Expected Years of Life Lost) was implemented to assess YLLs. Results. In 2000, the highest number of YLLs per 10,000 men was recorded in Zachodniopomorskie (55.7 years), and in 2014 - in Opolskie (77.5 years). The increasing tendency of this measure between 2000 and 2014 in the group of men was observed in all voivodships. In the group of women, in 2000 the highest number of YLLs per 10,000 was reported in Lodzkie (46 years), and in 2014 - in WarminskoMazurskie (49.6 years). In women, an SEYLL decline over time was noted only in Lodzkie and Dolnoslaskie, and in other voivodships, its values increased.

Conclusions. Between 2000 and 2014, an upward tendency of YLLs due to CRC was observed in Poland, though with territorial differentiation. It is advisable to search for more effective methods of reducing existing inequalities between individual provinces of Poland. Key words: colorectal neoplasms, social conditions, life expectancy, vital statistics.

Paciej-Gołębiowska P, Pikala M, Maniecka-Bryła I. Years of life lost due to colorectal cancer in Poland between 2000 and 2014 according to voivodships. Fam Med Prim Care Rev 2018; 20(3): 245-249, doi: https://doi.org/10.5114/fmpcr.2018.78260.

\section{Background}

Malignant neoplasms, along with cardiovascular diseases, are the most important causes of death among Europeans. It is estimated that more than every fourth death in the UE-28 countries is due to oncological causes - in 2014 , they caused $26.4 \%$ of all deaths, and the dominant share included neoplasms of the lungs $(20.1 \%$ of all cancer-related deaths), colorectum $(11.3 \%)$, breast $(6.9 \%)$ and prostate $(5.5 \%)[1]$.

To improve the epidemiological situation regarding malignant neoplasms in Europe, in 2003, the Council of the European Union introduced recommendations on screening programs aimed at early detection of malignancies of the colon (fecal occult blood test performed in people aged $50-74$ years), the breast (mammography performed in women between the age of 50-69 years) and the uterine cervix (cytological examination in women over 20-30 years of age) [2]. Unfortunately, these have not been widely translated into clinical practice as of yet. The results of the European Health Interview Survey (EHIS) from 2014 revealed that more than half of Europeans who qualified for screening for colorectal cancers (CRC) had never had a fecal occult blood test (including $81.7 \%$ of Poles), and just over $18 \%$ had this performed in the past 12 months before the survey (4.2\% in Poland) [3]. In some countries, a colonoscopy is also included in the screening for CRC. In Poland, personal invitations to these examinations have been sent to people aged 55-64 from 2012; however, the percentage of applications does not exceed $20 \%$ annually (the highest response rate was noted in 2014 and was $17.4 \%)$ [4].

According to Eurostat, the values of the standardized mortality rate due to CRC for the EU-28 has slightly improved recently, but still in many European countries, an adverse trend of mortality for this reason is observed. In 2011, in the EU-28, the rate was on average 32.05 per 100,000 inhabitants, while in 2015 , it was 30.40 per 100,000 . At that time, the death rate for Poland was 35.77 and 37.83 per 100,000, respectively. In 2015, the highest values of this measure were recorded in Hungary $(54.10$ per 100,000$)$, in Croatia $(49.95$ per 100,000$)$ and in Slovakia (49.48 per 100,000); they were the lowest in Cyprus (19.31 per 100,000$)$, in Finland $(21.84$ per 100,000$)$ and in Greece $(23.23$ per 100,000$)[1]$.

In many publications, attention is also drawn to differences in mortality for various reasons, not only between EU countries, but also between regions belonging to one country [5-10].

Currently, synthetic measures, such as DALY (Disability-adjusted Life Years) and its components YLL (Years of Life Lost) and YLD (Years of Life with Disability), are widely in use to assess the health status of a population [11]. YLL, in contrast to traditionally used mortality rates, takes into account not only the number of deaths, but also the age of the individuals at the moment of death. Therefore, it can be used to evaluate the socio-economic aspects of mortality due to different causes [12-14].

\section{Objectives}

The aim of this study was to compare YLLS due to CRC between 2000 and 2014 in Poland according to voivodships.

\section{Material and methods}

The study was based on a dataset containing information gathered from the death certificates of Poles who died in 2000 ( $n=368,028)$ and $2014(n=376,467)$, provided by the Central 
Statistical Office in Poland. Information on deaths caused by CRC was used for the analysis, i.e. covered by codes C18-C21 according to the International Classification of Diseases and Related Health Problems, $10^{\text {th }}$ Revision (ICD-10).

The SEYLL (Standard Expected Years of Life Lost) measure was used to assess YLLs. Its value was calculated in accordance with the method developed by Murray and Lopez [15]

$$
\text { SEYLL }=\sum_{\chi=0}^{\mathrm{I}} \mathrm{d}_{\chi} \mathrm{e}_{\chi}^{*}
$$

where:

$\mathrm{e}^{*} \mathrm{\chi}$ is the average life expectancy for a particular age determined based on standard population;

$d_{\chi}$ is the number of deaths at age $\chi$;

$\chi$ is the age of death:

$I$ is the oldest age in the population.

The expected lifespan for a given age was determined on the basis of the life table published by the World Health Organization (WHO) in 2012. According to this source, the life expectancy for both sexes at age 0 is 86.02 years [16].

We also implemented the SEYLL ${ }_{p}$ measure (Standard Expected Years of Life Lost per person), which is a ratio of YLLs to the number of a population, in this study calculated per 10,000 inhabitants; and the SEYLL measure (Standard Expected Years of Life Lost per death), which is a quotient of YLLs and the number of deaths caused by a particular disease.

The Bioethics Committee of the Medical University of Lodz gave consent for the study to be conducted (No. RNN/183/17KE of June 13, 2017).

\section{Results}

In 2000, CRCs were the cause of 8,517 deaths in the Polish population ( $2.3 \%$ of all deaths) $-4,373$ deaths of men and 4,144 deaths of women, while in 2014 , it was 11,411 deaths ( $3 \%$ of all deaths) $-6,423$ deaths in the group of men and 4,988 in the group of women. Data on the number of deaths due to CRC according to voivodships is given in Table 1.

\begin{tabular}{|c|c|c|c|c|}
\hline \multirow[t]{2}{*}{ Voivodship } & \multicolumn{2}{|l|}{ Men } & \multicolumn{2}{|c|}{ Women } \\
\hline & 2000 & 2014 & 2000 & 2014 \\
\hline Dolnoslaskie & 373 & 505 & 366 & 395 \\
\hline Kujawsko-pomorskie & 242 & 382 & 235 & 287 \\
\hline Lubelskie & 224 & 365 & 197 & 223 \\
\hline Lubuskie & 118 & 170 & 91 & 111 \\
\hline Lodzkie & 306 & 406 & 349 & 371 \\
\hline Malopolskie & 345 & 528 & 321 & 389 \\
\hline Mazowieckie & 598 & 829 & 603 & 691 \\
\hline Opolskie & 125 & 198 & 117 & 137 \\
\hline Podkarpackie & 201 & 271 & 157 & 209 \\
\hline Podlaskie & 112 & 202 & 132 & 161 \\
\hline Pomorskie & 248 & 370 & 222 & 305 \\
\hline Slaskie & 583 & 842 & 515 & 663 \\
\hline Swietokrzyskie & 138 & 213 & 124 & 167 \\
\hline Warminsko-mazurskie & 132 & 209 & 125 & 202 \\
\hline Wielkopolskie & 403 & 616 & 451 & 468 \\
\hline Zachodniopomorskie & 225 & 317 & 139 & 209 \\
\hline Total & 4,373 & 6,423 & 4,144 & 4,988 \\
\hline
\end{tabular}

These deaths translated into a total of $162,365.5$ YLLs in $2000\left(\mathrm{SEYLL}_{\mathrm{p}}=42.4\right.$ years $)-88,250.1 \mathrm{YLLs}$ in the group of men
$\left(\mathrm{SEYLL}_{p}=47.6\right.$ years) and 74,115.4 YLLs in the group of women $\left(\right.$ SEYLL $_{p}=37.6$ years); while in 2014, they caused 202,208.5 YLLS $\left(\mathrm{SEYLL}_{p}=52.6\right.$ years $)-119,700.4 \mathrm{YLLs}$ in men $\left(\mathrm{SEYLL}_{p}=64.3\right.$ years) and $82,508.1$ YLLs in women (SEYLL $=41.5$ years). The value of SEYLL in 2000 was on average 19.1 years - a man who died during that time due to CRC lost on average 20.2 years, and a woman lost 17.9 years; while in 2014, it was on average 17.7 years -18.6 years in the group of men and 16.5 years in the group of women.

In 2000, the highest number of YLLs per 10,000 men was recorded in the voivodship of Zachodniopomorskie $\left(\mathrm{SEYLL}_{\mathrm{p}}=55.7\right.$ years), while in 2014, it was the highest in the voivodship of Opolskie ( $S E Y L L=77.5$ years). An increase of the values of this measure between 2000 and 2014 was found in all voivodships (on average by 16.7 years), but in the voivodship of Opolskie, it was the highest (by 25.8 years). In 2000 , the lowest number of YLLs was noted for inhabitants of the voivodship of Podlaskie $\left(\mathrm{SEYLL}_{\mathrm{p}}=36.3\right.$ years$)$, and in 2014, it was for the voivodship of Podkarpackie ( $S E Y L L_{p}=48.3$ years). The latter was reported to have the lowest increase in SEYLL ${ }_{p}$ in the analyzed time (by 8.7 years) (Table 2).

Table 2. Years of life lost due to colorectal cancer in men in Poland in 2000 and 2014 according to voivodships

\begin{tabular}{|l|l|l|l|l|}
\hline \multirow{2}{*}{ Voivodships } & \multicolumn{3}{|l|}{ SEYLL $_{\mathrm{p}}$} & \multicolumn{2}{l|}{ SEYLL $_{d}$} \\
\cline { 2 - 5 } & 2000 & 2014 & 2000 & 2014 \\
\hline Dolnoslaskie & 53.6 & 68.9 & 20.1 & 19.1 \\
\hline Kujawsko-pomorskie & 50.0 & 71.4 & 20.6 & 18.9 \\
\hline Lubelskie & 41.2 & 66.4 & 19.7 & 18.9 \\
\hline Lubuskie & 54.1 & 67.1 & 22.5 & 19.6 \\
\hline Lodzkie & 48.5 & 64.8 & 19.9 & 19.0 \\
\hline Malopolskie & 44.6 & 57.0 & 20.3 & 17.6 \\
\hline Mazowieckie & 45.9 & 59.2 & 18.9 & 18.2 \\
\hline Opolskie & 51.7 & 77.5 & 21.5 & 18.9 \\
\hline Podkarpackie & 39.6 & 48.3 & 20.3 & 18.6 \\
\hline Podlaskie & 36.3 & 60.5 & 19.2 & 17.4 \\
\hline Pomorskie & 46.0 & 59.3 & 19.6 & 18.0 \\
\hline Slaskie & 53.4 & 69.4 & 21.1 & 18.2 \\
\hline Swietokrzyskie & 45.3 & 63.9 & 20.9 & 18.5 \\
\hline Warminsko-mazurskie & 38.1 & 60.1 & 20.1 & 20.3 \\
\hline Wielkopolskie & 49.4 & 71.1 & 19.9 & 19.5 \\
\hline Zachodniopomorskie & 55.7 & 71.1 & 20.5 & 18.7 \\
\hline Total & $\mathbf{4 7 . 6}$ & $\mathbf{6 4 . 3}$ & $\mathbf{2 0 . 2}$ & $\mathbf{1 8 . 6}$ \\
\hline
\end{tabular}

SEYLL - Standard Expected Years of Life Lost per person (per 10.000); $\mathrm{SEYLL}_{d}$ - Standard Expected Years of Life Lost per death.

In the group of women, in 2000, the highest number of YLLS

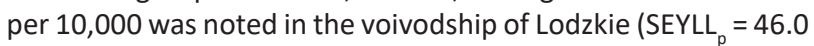
years), and in 2014, it was in the voivodship of Warminsko-Mazurskie ( $\mathrm{SEYLL}_{\mathrm{p}}=49.6$ years). In the context of the whole of Poland, between 2000 and 2014, the SEYLL value increased by 4.0 years, but the highest increase was recorded in female inhabitants of the voivodship of Warminsko-Mazurskie (by 18.0 years). On the contrary, in the voivodships of Lodzkie and Dolnoslaskie, the occurrence of a downward tendency of SEYLL ${ }_{p}$ was revealed at the level of -2.6 and -2.4 years, respectively. In the analyzed time, the lowest SEYLL values were noted in the voivodship of Podkarpackie (in $2000-\mathrm{SEYLL}_{\mathrm{p}}=25.9$ years; in $2014-\mathrm{SEYLL}_{\mathrm{p}}=$ 31.9 years) (Table 3 ).

The value of $\mathrm{SEYLL}_{d}$ in the group of men who died in 2000 ranged between 18.9 years in the voivodship of Mazowieckie and 22.5 years in the voivodship of Lubuskie; while in 2014, it ranged between 17.4 years in the voivodship of Podlaskie and 20.3 years in the voivodship of Warminsko-Mazurskie. Only in 
the voivodship of Warminsko-Mazurskie was there an upward tendency of $S E Y L L_{d}$ over time (by 0.2 years).

\begin{tabular}{|c|c|c|c|c|}
\hline \multirow[t]{2}{*}{ Voivodship } & \multicolumn{2}{|c|}{ SEYLL $p_{p}$} & \multicolumn{2}{|c|}{ SEYLL $_{d}$} \\
\hline & 2000 & 2014 & 2000 & 2014 \\
\hline Dolnoslaskie & 45.2 & 42.8 & 18.7 & 16.3 \\
\hline Kujawsko-pomorskie & 40.2 & 43.3 & 18.3 & 16.2 \\
\hline Lubelskie & 30.6 & 34.2 & 17.6 & 17.0 \\
\hline Lubuskie & 33.9 & 34.5 & 19.3 & 16.3 \\
\hline Lodzkie & 46.0 & 43.3 & 18.1 & 15.3 \\
\hline Malopolskie & 34.7 & 37.3 & 18.0 & 16.6 \\
\hline Mazowieckie & 39.3 & 39.9 & 17.3 & 16.1 \\
\hline Opolskie & 40.1 & 43.1 & 18.8 & 16.2 \\
\hline Podkarpackie & 25.9 & 31.9 & 17.7 & 16.6 \\
\hline Podlaskie & 36.2 & 40.0 & 16.9 & 15.2 \\
\hline Pomorskie & 33.5 & 43.0 & 16.8 & 16.6 \\
\hline Slaskie & 38.0 & 47.9 & 18.1 & 17.1 \\
\hline Swietokrzyskie & 34.4 & 43.9 & 18.5 & 17.0 \\
\hline Warminsko-mazurskie & 31.7 & 49.6 & 18.5 & 18.1 \\
\hline Wielkopolskie & 45.0 & 45.1 & 17.2 & 17.2 \\
\hline Zachodniopomorskie & 30.0 & 39.2 & 18.8 & 16.5 \\
\hline Total & 37.6 & 41.5 & 17.9 & 16.5 \\
\hline
\end{tabular}

SEYLL $_{p}$ - Standard Expected Years of Life Lost per person (per 10.000); $\mathrm{SEYLL}_{d}$ - Standard Expected Years of Life Lost per death.

In the group of women, the SEYLL ${ }_{d}$ value was the lowest in the voivodship of Pomorskie -16.8 years, and it was the highest in the voivodship of Lubuskie - 19.3 years. In 2014, it ranged between 15.2 years in the voivodship of Podlaskie and 18.1 years in the voivodship of Warminsko-Mazurskie. Between 2000 and 2014 , the value of SEYLL among women decreased in every voivodship.

\section{Discussion}

The results of the study confirmed the presence of an unfavorable epidemiological situation regarding CRC in Poland. Comparison of YLLs between 2000 and 2014 revealed an upward trend in both sexes, though with significant territorial differences. In 2000, SEYLL ${ }_{p}$, both in men and in women, was above the national average in six of the sixteen voivodships, while in 2014, it concerned nine of them.

In comparison to other regions, the situation of women in the voivodship of Warminsko-Mazurskie seems to be particularly disadvantageous. In 2014, SEYLL was in this voivodship the highest in Poland, and it amounted to 49.6 years. Additionally, the largest increase of $S E Y L L_{p}$ over time was recorded here - in 2000, it was 18 years lower. In this voivodship, in 2014 in both sexes, the SEYLL values were also among the highest, and what is more, it was the only voivodship in which an increase of this measure in the group of men was found over time.

On the contrary, a relatively good situation, compared to others, was reported in the voivodship of Podkarpackie - in 2014 in both sexes, the lowest SEYLL values were recorded here, and in the group of women, this was also the case in 2000. Besides this, in the group of men, the SEYLL increase over time in this voivodship was the lowest in Poland.

Available data indicates that in 2014, standardized mortality rates due to CRC were the lowest in the voivodship of Podkarpackie (17.3 per 100,000 inhabitants), while the worst situation was recorded in the voivodship of Wielkopolskie (23.9 per
$100,000)$. Only an analysis of deaths rates in the age group 25-64 revealed results consistent with ours, i.e. the highest death rate among men was noted in the voivodship of Opolskie (21.1 per 100,000), and among women in the voivodship of Warminsko-Mazurskie (11.4 per 100,000) [17].

An important supplement to the analysis of prematurely lost years of life is the assessment of changes of SEYLL ${ }_{d}$ over time. Virtually throughout Poland (except for the voivodship of Warmisko-Mazurskie in the group of men), a downward trend was recorded. This demonstrates the slow shifting of deaths from CRC to older age groups. This is mainly due to the increasing lifespan and aging of the Polish populations, and to a much lesser extent to the improvement of CRC treatment [18, 19].

A study conducted on the population of the voivodship of Lodzkie revealed that in 1990-2008 among men, CRCs were the second most important cause of YLLs in the group of oncological diseases, after malignant neoplasms of the trachea, bronchi and lungs, and in the group of women, CRCs were second after malignant neoplasms of the trachea, bronchi and lungs and malignant neoplasms of the breast [20]; while a study on the whole Polish population showed that in 2011, out of all disease entities, CRCs were the twelfth most important cause of YLLs among men (1.5\% of all YLLs), and tenth in the group of women $(2.2 \%$ of all YLLS) [21].

According to the Global Burden of Disease (GBD), in 2015, CRC caused a loss of approximately 54.2 years of life per 10,000 inhabitants of EU-28, while in Poland, it was 66.2 years per 10,000 . The highest number of YLLs due to this cause were noted in Hungary - 97.8 years per 10,000 , in Croatia - 85.9 years per 10,000, and in Slovakia - 73.4 years per 10,000 [22].

The recognized risk factors for CRC include: a diet rich in red meat and highly processed food, heat treatment of meat by its frying or grilling, obesity, excessive consumption of alcohol, cigarette smoking, sedentary lifestyle [23-25]. However, the causes of this unfavorable phenomena in the field of prematurely lost years of life due to CRC can be seen in the deterioration of the health attitudes of Poles and the gradual acceptance of a so-called "western lifestyle" [26-28].

In the WOBASZ study (Multi-Center National Population Health Survey), which was conducted in 2003-2005 in Poland, the existence of regional variations in an obedience of health habits was revealed. Analysis of the level of physical activity showed that the highest number of men performing physical activity within the recommended range resided the voivodships of Lubelskie (51\%) and Opolskie (47\%), while the lowest were in the voivodships of Podlaskie (26\%) and Slaskie (32\%). Similarly, the female residents of the voivodships of Lubelskie $(50 \%)$ and Opolskie $(46 \%)$ were most active, but in the voivodships of Pomorskie (25\%) and Slaskie (25\%), they were the least [29]. In terms of tobacco smoking status, the highest number of men currently smoking was noted in the voivodship of Podlaskie $(48 \%)$, and smoking women were dominant in the voivodship of Warminsko-Mazurskie (34\%) [30]. The highest number of obese men were recorded in the voivodship of Wielkopolskie $(28.2 \%)$, and the lowest in the voivodship of Malopolskie (14.25); while the highest share of obese women was noted in the voivodship of Opolskie (24.0\%), and the lowest in the voivodship of Podkarpackie (16.1\%) [31]. The highest consumption of meat (in grams per day) was recorded in the voivodships of Podlaskie and Warminsko-Maurskie, while the lowest was in the voivodship of Podkarpackie [32]. Therefore, it seems that this last factor may play a leading role in diversifying the number of YLLs due to CRC in individual provinces.

Comparison of the WOBASZ survey results from 2003-2005 with its subsequent edition from 2013-2014 also revealed the occurrence of disturbing changes in time in the Polish population, such as the decrease in practicing regular physical activity from $37.4 \%$ to $27.3 \%$ in the group of men and from $32.7 \%$ to $28.3 \%$ in the group of women [27], or an increase in the percentage of people with abnormal body mass - from $61.6 \%$ to 
$69 \%$ in the group of men, and from $50.3 \%$ to $59 \%$ in the group of women [31].

Undeniably, excessive alcohol consumption is also an important cause of premature loss of life in Poland. According to the $\mathrm{GBD}$, among all disease risk factors, alcohol is the sixth most significant cause of DALY in the Polish population, after elevated blood pressure, cigarette smoking, abnormal body weight, elevated total cholesterol and impaired fasting glucose [33]. As indicate WHO data, the amount of alcoholic beverages consumed by Poles is still increasing - between 2000 and 2014, the consumption of pure alcohol increased from 8.40 to 10.71 liters per capita [34]. This is reflected in the predominant contribution of alcoholic liver disease and fibrosis and cirrhosis of the liver in YLLs in the group of chronic diseases of the digestive system with a non-cancerous etiology in Poland $[35,36]$. In addition, data from 2011 indicated that liver cirrhosis was the third, after car accidents and suicides, cause of YLLs per death (SEYLL $)$ [21].
Limiting the consumption of alcohol by Poles could affect the reduction of YLLs, not only due to liver diseases associated with excessive alcohol use, but also due to CRC.

\section{Conclusions}

Over the years 2000 to 2014, an increase in the number of YLLs due to CRC in Poland was observed, and this phenomenon was characterized by territorial diversity. One of the reasons may be the deteriorating health habits of Poles. It is not possible to determine which risk factors affected the inequalities between voivodships to the greatest extent, but it seems that one of them may be the quantity and type of meat consumed.

It is advisable to continue research on territorial distribution of possible risk factors for CRC and to search for more effective methods of reducing existing inequalities between individual provinces of Poland.

Source of funding: The study was financed by the Medical University of Lodz (Grant number 502-03/6-029-07/502-64-113). Conflict of interest: The authors declare no conflict of interests.

\section{References}

1. Eurostat Statistics [cited 21.04.2018]. Available from URL: http://ec.europa.eu/eurostat/web/ health/causes-death/data/database.

2. Official Journal of the European Union, L 327, 16 December 2003 [cited 21.04.2018]. Available from URL: http://eur-lex.europa.eu/ legal-content/EN/TXT/?uri=OJ:L:2003:327:TOC.

3. European Health Interview Survey. Eurostat [cited 21.04.2018]. Available from URL: http://ec.europa.eu/eurostat/cache/metadata/ en/hlth_det_esms.htm.

4. Program badań przesiewowych raka jelita grubego [cited 25.04.2018]. Available from URL: http://pbp.org.pl/ (in Polish).

5. Borrell C, Mari-Dell'Olmo M, Serral G, et al. Inequalities in mortality in small areas of eleven Spanish cities (the multicenter MEDEA project). Health Place 2010; 16(4): 703-711.

6. Reques L, Miqueleiz E, Giráldez-García C, et al. Geographic patterns of mortality and socioeconomic inequalities in mortality in Spain. Rev Esp Salud Publica 2015; 89(2): 137-147.

7. Eames M, Ben-Shlomo Y, Marmot MG. Social deprivation and premature mortality: regional comparison across England. BMJ 1993; 307, doi: https://doi.org/10.1136/bmj.307.6912.1097.

8. Drever F, Whitehead M. Mortality in regions and local authority districts in the 1990s: exploring the relationship with deprivation. Popul Trends 1995; 82: 19-26.

9. Ghosn W, Kassié D, Jougla E, et al. Trends in geographic mortality inequalities and their association with population changes in France, 1975-2006. Eur J Public Health 2013; 23(5): 834-840.

10. Pikala M, Burzyńska M, Maniecka-Bryła I. Territorial differences in years of life lost due to premature mortality in inhabitants of Poland. Przegl Epidemiol 2017; 71(1): 68-79.

11. Kassebaum MJ, Arora M, Barber RM, et al. Global, regional, and national disability-adjusted life years (DALYs) for 315 diseases and injuries and healthy life expectancy (HALE), 1990-2015: a systemic analysis for Global Burden of Disease Study 2015. Lancet 2016; 388(10053): 1603-1658.

12. Marshall RJ. Standard Expected Years of Life Lost as a measure of disease burden: an investigation of its presentation, meaning and interpretation. In: Preedy VR, Watson RR, eds. Handbook of disease burdens and quality of life measures. Berlin: Springer; 2009: 3421-3434.

13. Pikala M, Maniecka-Bryła I. Socioeconomic inequalities in mortality due to all causes in the working age population of Poland in 2002 and 2011. Med Pr 2017; 68(6): 771-778.

14. Pikala M, Burzyńska M, Pikala R, et al. Educational inequalities in premature mortality in Poland, 2002-2011: a population-based crosssectional study. BMJ Open 2016; 6(9): e011501, doi: 10.1136/bmjopen-2016-011501.

15. Murray CJL, Lopez AD. The global burden of disease. A comprehensive assessment of mortality and disability from diseases, injuries and risk factors in 1990 and projected to 2010. Boston: Harvard University Press; 1996.

16. Supplement to: Murray CJL, Ezzati M, Flaxman AD, et al. GBD 2010: design, definitions, and metrics. Lancet 2012; 380(9859): 2063-2066 .

17. Wojtyniak B, Goryński P. Sytuacja zdrowotna ludności Polski. Warszawa: Narodowy Instytut Zdrowia Publicznego - Państwowy Zakład Higieny; 2016 (in Polish).

18. Paciej-Gołębiowska P, Pikala M, Maniecka-Bryła I. Years of life lost due to malignant neoplasms of the digestive system in Poland in 2000-2014. United European Gastroenterol J 2018; 6(6): 943-951.

19. Kubiak A, Kycler W, Trojanowski M. Epidemiology and prevention of colorectal cancer in Poland. Probl Hig Epidemiol 2014 ; 95: 636-642.

20. Pikala M, Maniecka-Bryla I. Years of life lost due to malignant neoplasms characterized by the highest mortality rate. Arch Med Sci 2014; 10(5): 999-1006.

21. Maniecka-Bryła I, Bryła M, Bryła P, Pikala M. The burden of premature mortality in Poland analysed with the use of standard expected years of life lost. BMC Public Health 2015; 15: 101, doi: 10.1186/s12889-015-1487-x.

22. Global Health Data Exchange [cited 26.04.2018]. Available from URL: http://ghdx.healthdata.org/gbd-results-tool.

23. Lee DH, Keum N, Giovannucci EL. Colorectal cancer epidemiology in the nurses' health study. Am J Public Health 2016; 106: 1599-1607.

24. Haggar FA, Boushey RP. Colorectal cancer epidemiology: incidence, mortality, survival, and risk factors. Clin Colon Rectal Surg 2009; 22(4): 191-197.

25. American Cancer Society. Cancer facts \& figures 2017. Atlanta, Ga: American Cancer Society; 2017.

26. Kwaśniewska M, Bielecki W, Kaczmarczyk-Chałas K, et al. Prevalence of healthy lifestyle in adult residents of Łodz and Lublin voivodeships - Project WOBASZ. Prz Lek 2007; 64: 61-64. 
27. Kwaśniewska M, Pikala M, Bielecki W, et al. Ten-year changes in the prevalence and socio-demographic determinants of physical activity among Polish adults aged 20 to 74 years. Results of the National Multicenter Health Surveys WOBASZ (2003-2005) and WOBASZ II (2013-2014). PLOS ONE 2016; 11(6): e0156766, doi: 10.1371/journal.pone.0156766.

28. Maniecka-Bryła I, Drygas W, Bryła M, et al. Determinants of self-rated health among the elderly living in a big city environment. Pol J Environ Stud 2011; 20(3): 691-699.

29. Drygas W, Kwaśniewska M, Szcześniewska D, et al. Ocena poziomu aktywności fizycznej dorosłej populacji Polski. Wyniki programu WOBASZ. Kardiol Pol 2005; 63(Supl. 4): S1-S5 (in Polish).

30. Polakowska M, Piotrowski W, Tykarski A, et al. Nałóg palenia tytoniu w populacji polskiej. Wyniki programu WOBASZ. Kardiol Pol 2005; 63(Supl. 4): S1-S6 (in Polish).

31. Stepaniak U, Micek A, Waśkiewicz A, et al. Prevalence of general and abdominal obesity and overweight among adults in Poland. Results of WOBASZ II study (2013-2014) and comparison with WOBASZ study (2003-2005). Pol Arch Med Wewn 2016; 126 : 662-671.

32. Sygnowska E, Waśkiewicz A, Głuszek J, et al. Spożycie produktów spożywczych przez dorosłą populację Polski. Wyniki programu WOBASZ. Kardiol Pol 2005; 63(Supl. 4): S1-S7 (in Polish).

33. Forouzanfar $\mathrm{MH}, \mathrm{Afshin} \mathrm{A}$, Alexander LT, et al. Global, regional and national comparative risk assessment of 79 behavioral, environmental and occupational, and metabolic risks or cluster of risks, 1990-2015: a systematic analysis for the Global Burden of Disease Study 2015. Lancet 2016; 388(10053): 1659-1724.

34. World Health Organization Regional Office for Europe. European health for all database [cited 24.04.2018]. Available from URL: http:// data.euro. who.int/hfadb/.

35. Paciej P, Ciabiada B, Maniecka-Bryła I. Lost Life Years Due to premature deaths caused by diseases of the digestive system in Poland in 2013. Przegl Epidemiol 2016; 70(3): 500-507.

36. Paciej P, Ciabiada B, Maniecka-Bryła I. Premature mortality due to alcohol-related diseases of the liver in Poland according to voivodships. Fam Med Prim Care Rev 2017; 19(3): 251-255.

Tables: 3

Figures: 0

References: 36

Received: 27.04.2018

Reviewed: 01.05.2018

Accepted: 13.05 .2018

Address for correspondence:

Paulina Paciej-Gołębiowska, MD

Zakład Epidemiologii i Biostatystyki UM

pl. Hallera 1, budynek II

90-742 Łódź

Polska

Tel.: +48 609 915-997

E-mail: paulina.paciej@stud.umed.lodz.pl 